\title{
Fecal DNA isolation and degradation in clam Cyclina sinensis: noninvasive DNA isolation for conservation and genetic assessment
}

\author{
Min Zhang ${ }^{1+}$, Min Wei ${ }^{1,2+}$, Zhiguo Dong ${ }^{1,2^{*}}$, Haibao Duan', Shuang Mao', Senlei Feng ${ }^{1}$, Wenqian $\mathrm{Li}^{1}$, Zepeng Sun ${ }^{1}$, \\ Jiawei Li', Kanglu Yan', Hao Liu', Xueping Meng ${ }^{1}$ and Hongxing Ge ${ }^{1,2}$
}

\begin{abstract}
Background: To avoid destructive sampling for conservation and genetic assessment, we isolated the DNA of clam Cyclina sinensis from their feces. DNA electrophoresis and PCR amplification were used to determine the quality of fecal DNA. And we analyzed the effects of different conditions on the degradation of feces and fecal DNA.

Results: The clear fecal DNA bands were detected by electrophoresis, and PCR amplification using clam fecal DNA as template was effective and reliable, suggesting that clam feces can be used as an ideal material for noninvasive DNA isolation. In addition, by analyzing the effects of different environmental temperatures and soaking times on the degradation of feces and fecal DNA, we found that the optimum temperature was $4^{\circ} \mathrm{C}$. In 15 days, the feces maintained good texture, and the quality of fecal DNA was good. At $28^{\circ} \mathrm{C}$, the feces degraded in 5 days, and the quality of fecal DNA was poor.
\end{abstract}

Conclusions: The clam feces can be used as an ideal material for noninvasive DNA isolation. Moreover, the quality of fecal DNA is negatively correlated with environmental temperature and soaking time.

Keywords: Cyclina sinensis, Feces; noninvasive DNA isolation, DNA degradation

\section{Background}

The clam Cyclina sinensis is an economically important marine bivalve that is abundant and widely distributed around the maritime coasts of Asia. C. sinensis is a kind of eurythermal and euryhaline filter-feeding clam, and its food source mainly includes planktonic microalgae (Nannochloropsis oculata, Chaetoceros muelleri, Isochrysis galbana,etc.) [1,2] and the remains of organic debris by filtering water and sometimes opepods, facilitating the formation of fecal texture. C. sinensis has two hard and symmetrical shells on both sides, and it will quickly close the shells to protect itself from damage when it is stimulated by outside environment. Destructive and

\footnotetext{
* Correspondence: dzg7712@163.com

${ }^{\dagger}$ Min Zhang and Min Wei contributed equally to this work.

'Jiangsu Key Laboratory of Marine Biotechnology, Jiangsu Ocean University, Lianyungang 222005, Jiangsu, China

${ }^{2}$ Co-Innovation Center of Jiangsu Marine Bio-industry Technology, Jiangsu Ocean University, Lianyungang 222005, Jiangsu, China
}

nondestructive sampling methods are often applied in scientific researches of clam [3, 4]. The former is conducted by taking parts of specific tissue after the experimental animals are dissected directly, whereas the latter is usually completed by means of a shell opener or a mini electric drill. Nevertheless, sampling using both methods will negatively influence the life of clams, even leading to their death.

Noninvasive sampling is a sampling method for genetic analysis by collecting exfoliated hair, feces, and urine without having to catch, handle, or even observe the animals [5]. It has been widely used in the field of conservation genetics because it is simple and does not harm experimental animals. At present, noninvasive sampling methods are being applied to fish and marine mammals by collecting body surface mucus [6], shedding scales [7], and feces [8,9]. Among them, feces can be easily collected without disturbing or negatively affecting the 
normal life of experimental animals. Therefore, feces are potentially valuable research materials in noninvasive sampling. The main component of feces is undigested food residues, where intestinal epithelial cells adhere to when they pass through the intestine. Therefore, mitochondrial and nuclear genomic DNA can be isolated from the remaining epithelial cells in the feces [10]. Fecal molecular biotechnology provides a rapid and dependable way of sampling endangered animals [11-14]. In addition, with the development of molecular biology technology, fecal DNA is extensively used in genetic biology studies for species identification [15-17], individual identification [18-20], sex identification [21-25], population genetic structure [26-28], and genetic diversity evaluation [29]. However, fecal sampling has some problems, such as poor fecal DNA isolation quality and low success rate of PCR amplification [30]. Moreover, no study has performed fecal DNA extraction on invertebrates, especially shellfish. Studies on terrestrial animals have found that fecal DNA degradation occurs with the increase of exposure time [31] and is affected by many other factors, such as light, temperature, and humidity $[32,33]$. Compared with those of terrestrial animals, the feces of aquatic animals are more vulnerable due to the external water environment, and their fecal DNA is easier to degrade. Therefore, to obtain good quality shellfish fecal DNA, an improved fecal DNA extraction method should be developed, and the optimal environmental conditions for fecal sampling should be investigated.

In this study, clam feces was used as an experimental material to isolate DNA noninvasively. Moreover, the effects of environmental temperature and soaking time on the degradation of feces and fecal DNA were analyzed. The results can be used as a basis for developing noninvasive DNA isolation technology of shellfish and provide a reference for optimal conditions of fecal sampling, providing technical support for further research on molecular biology and conservation genetics of shellfish.

\section{Results}

\section{DNA isolation of fresh feces}

To determine the quality of fecal DNA, electrophoresis was conducted, and the foot muscle DNA was chosen as the positive control. The results showed that all bands of the fecal DNA were clear but showed a slight tailing phenomenon (Fig. 1 and Additional file 1: Figure S1), which was proved by the results of A260/280 (Table 1). Moreover, the bands of fecal DNA in lanes 2, 4, 5, and 6 were very bright, similar to the foot DNA band (lane F).

\section{PCR amplification}

To determine the effectiveness of fecal DNA, PCR amplification was conducted using the specific primers designed on the basis of mitochondrial and nuclear genomic DNA of $C$. sinensis. The results revealed that the band size of fecal DNA was the same as that of foot DNA and consistent with the expected length of the target band (Fig. 2 and Additional file 2: Figure S2), which was also proved by the sequencing results.

\section{Effects of soaking time and environmental temperature on fecal degradation}

Fecal degradation was evaluated by observing changes in fecal texture using a stereoscope. The fecal texture changed over time and was influenced by the environmental temperature. The fresh fecal pellets ( 0 days) were yellowish green in color and cylindrical. They had a length of $700 \mu \mathrm{m}$ and diameter of $450 \mu \mathrm{m}$ (Fig. 3). In fecal samples stored at $28^{\circ} \mathrm{C}$ (Fig. 3a), the surface texture became loose at 5 days, with filaments growing abundantly. The filaments grew in large numbers and gradually formed into microbial micelles. More bacteria attached to the microbial micelles, eventually forming bacterial micelles. At 10 and 15 days, the loose feces obviously broke apart, and the local fecal textures were decomposed. At 20 days, the breakage sites increased, and the fecal pellets became looser. At 25 days, the fecal pellets developed into bioflocs framed with filamentous fungi. In fecal

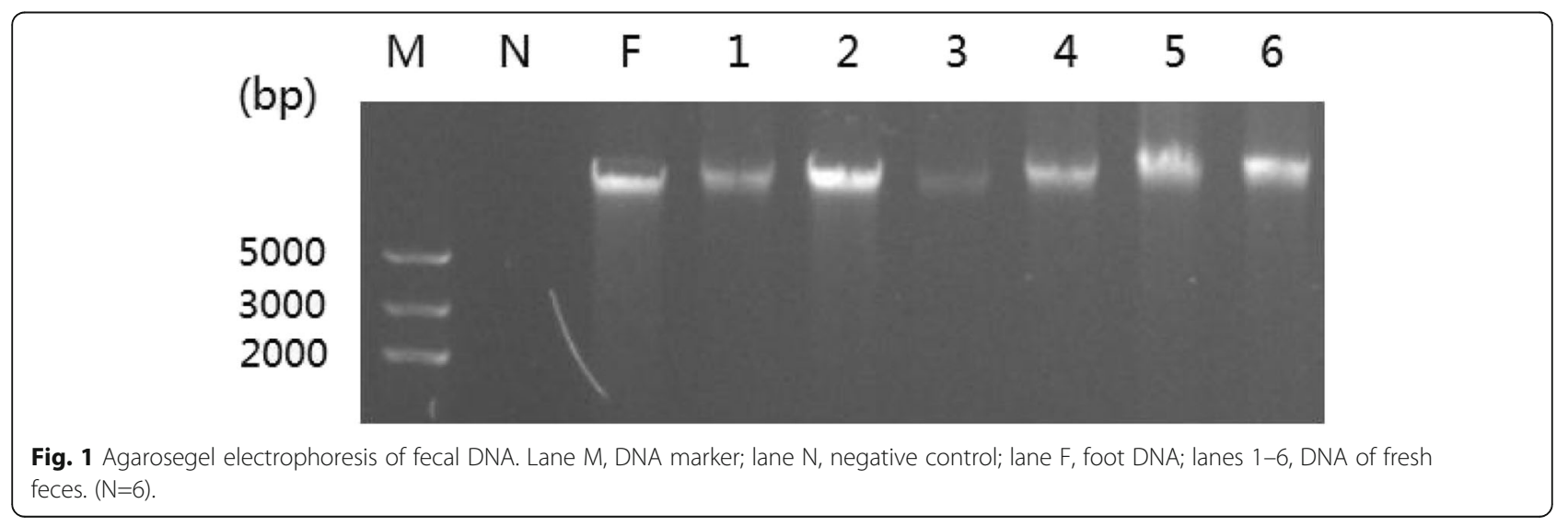


Table 1 DNA quality of fresh feces $(N=6)$

\begin{tabular}{lll}
\hline Fecal DNA & A260/280 & Concentration $(\mathrm{ng} / \mu \mathrm{L})$ \\
\hline 1 & 1.62 & 24.2 \\
2 & 1.79 & 27.3 \\
3 & 1.59 & 20.5 \\
4 & 1.70 & 24.3 \\
5 & 1.67 & 23.6 \\
6 & 1.77 & 25.1 \\
\hline
\end{tabular}

samples stored at $15^{\circ} \mathrm{C}$ (Fig. 3b), some fecal textures were slightly decomposed on the 10th day. Fecal breakage sites gradually increased at 15-20 days, and large cracks were observed at 25 days. In fecal samples stored at $4{ }^{\circ} \mathrm{C}$ (Fig. 3c), the fecal texture was not loose until 10 days and became slightly loose at 15 days. At $20-25$ days, some parts of the fecal pellets were slightly decomposed.

\section{Effects of soaking time and environmental temperature on fecal DNA degradation}

Under different soaking times and environmental temperatures, the degradation degree of fecal DNA was determined by agarose gel electrophoresis. At $28^{\circ} \mathrm{C}$, fecal DNA degradation occurred at 5 days after soaking the feces in seawater, but high-quality DNA could still be isolated from few fecal samples (Fig. 4a and Additional file 3: Figure S3a). At 15 and 20 days after soaking, poor-quality DNA was obtained from fecal samples, and serious fecal DNA degradation was observed. At $15{ }^{\circ} \mathrm{C}$, good-quality fecal DNA could still be extracted at 10 days after soaking (Fig. 4b and Additional file 3: Figure S3b); however, the sample degraded to varying degrees after 15 days. At $4{ }^{\circ} \mathrm{C}$, high-quality DNA without tailing phenomenon could still be obtained from fecal samples at 15 days after soaking (Fig. 4c and Additional file 3: Figure S3c).

\section{Discussion}

Using the modified phenol/chloroform method for fecal DNA isolation and PCR verification

Feces is a very complex mixture of biotic and abiotic components. In this study, DNA was extracted from clam feces, and the quality of fecal DNA was identical to that of foot DNA. As shown in Fig. 2, four specific fragments of mitochondrial and nuclear genomic DNA from C. sinensis were amplified by PCR using the fecal DNA as template. The results suggest that the isolation of fecal DNA was successful and reliable, which were proved by sequencing results. Therefore, clam DNA can be nondestructively isolated from feces. However,

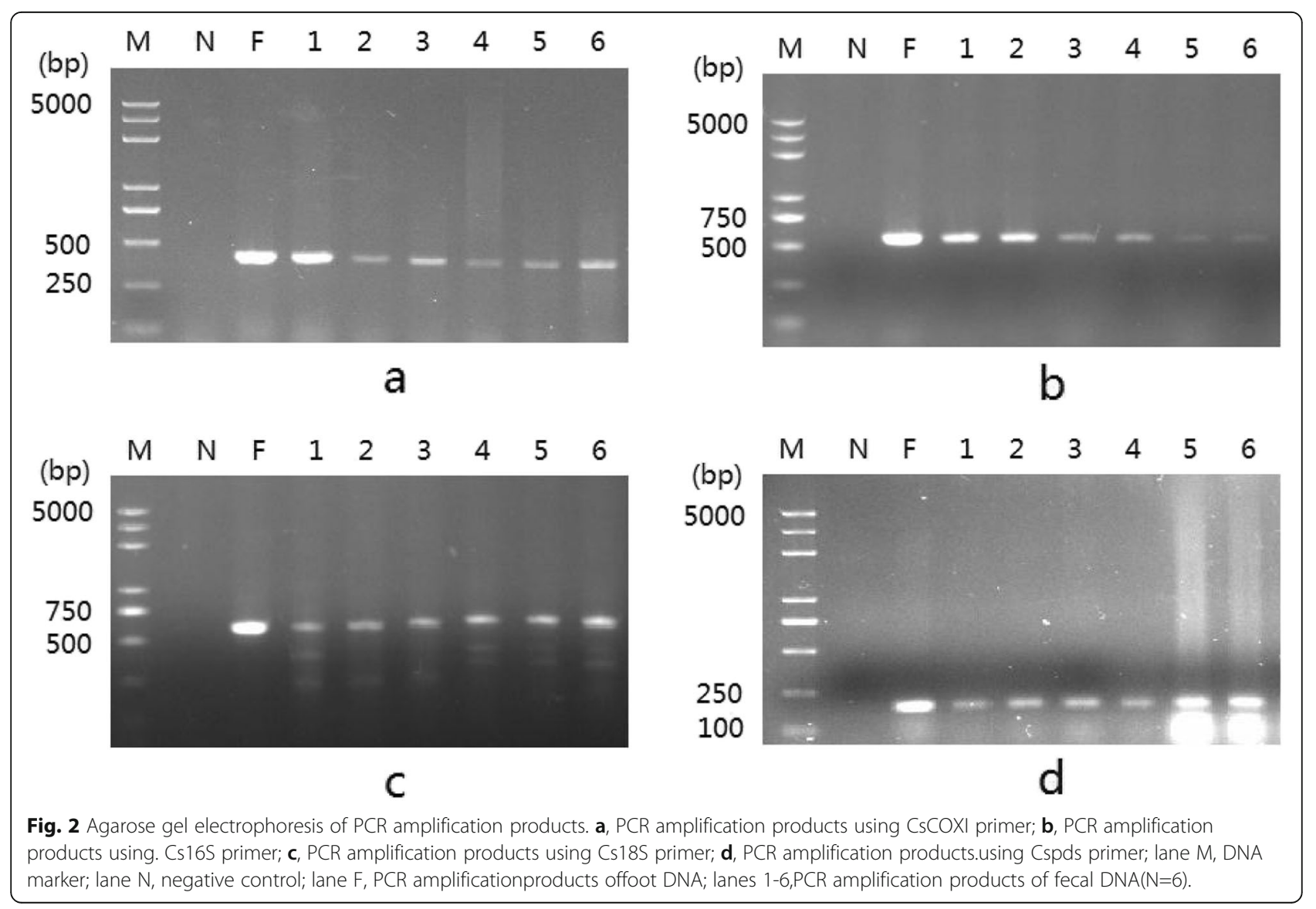




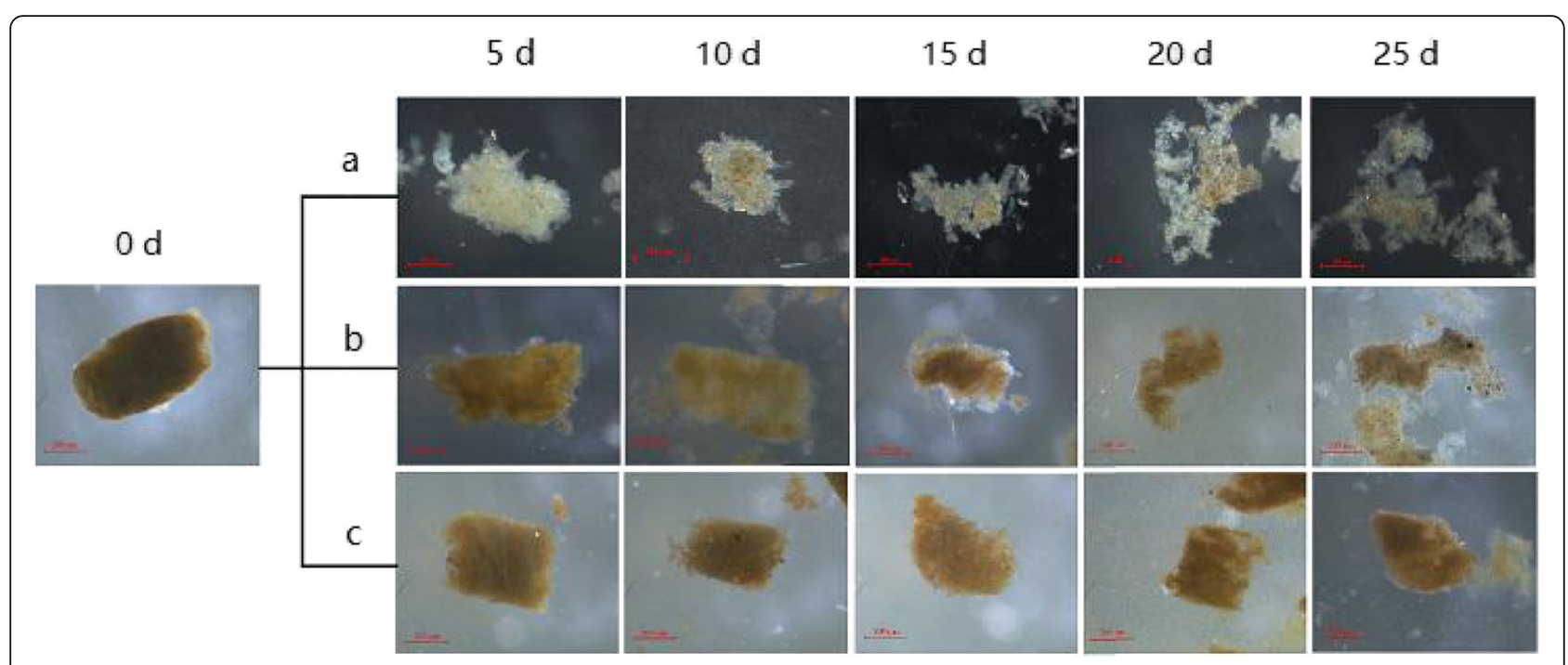

Fig. 3 Fecal textures of samples stored at $28^{\circ} \mathrm{C}(\mathbf{a}), 15^{\circ} \mathrm{C}(\mathbf{b})$, and $4^{\circ} \mathrm{C}(\mathbf{c})$

a

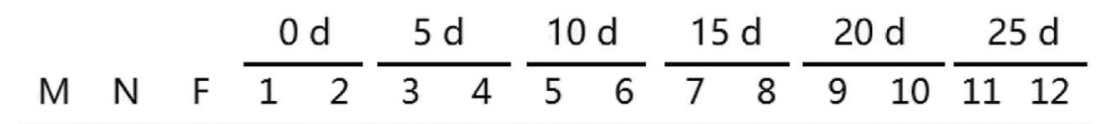

(bp)

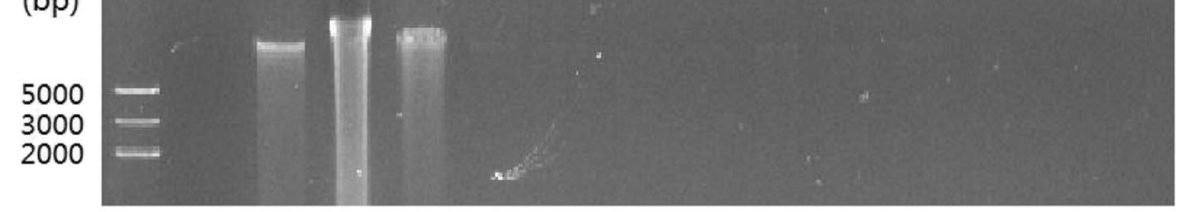

b $\quad M \quad F \frac{0 d}{142} \frac{5 d}{34} \frac{10 d}{5 \quad 6} \frac{15 d}{7 \quad 8} \frac{20 d}{910} \frac{25 d}{1112}$

(bp)

5000

3000

2000

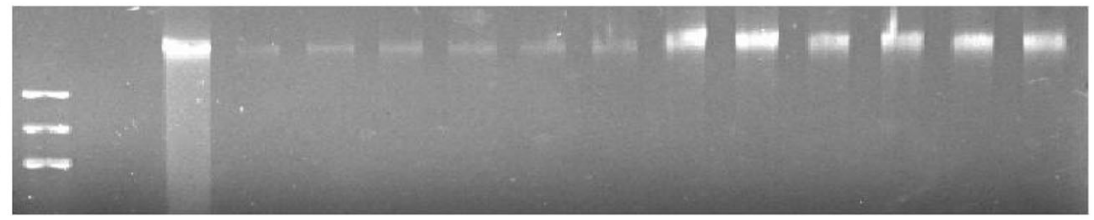

c $\quad \mathrm{M} / \mathrm{N} \frac{0 \mathrm{~d}}{12} \frac{5 \mathrm{~d}}{34} \frac{10 \mathrm{~d}}{5 \quad 6} \frac{15 \mathrm{~d}}{7 \quad 8} \frac{20 \mathrm{~d}}{9 \quad 10} \frac{25 \mathrm{~d}}{1112}$

(bp)

5000

3000

2000

Fig. 4 Agarose gel electrophoresis of DNA isolated from clam feces under different soaking times and environmental temperatures. Samples stored at $28^{\circ} \mathrm{C}(\mathbf{a}), 15^{\circ} \mathrm{C}(\mathbf{b})$, and $4^{\circ} \mathrm{C}(\mathbf{c})$. Lane M, DNA marker; lane N, negative control; lane. F, foot DNA of clam; lanes 1-12, fecal DNA. 
differences in the quality of fecal DNA were still observed among different fecal samples, which may be due to the quantity variance of intestinal cells adhered to feces. Besides intestinal cells, feces contain undigested food, digestive enzymes, mucus, and other blockers, which affect Taq DNA polymerase activity [34-36]. Furthermore, by extracting fecal DNA from diet-restricted brown bears, Murphy et al. found that the diet has a significant effect on the success rate of PCR amplification using fecal DNA as template [22]. In this study, the success rate of PCR amplification using fecal DNA as template was $100 \%$. This finding can be explained by two factors: (i) C. sinensis have special feeding habits (mostly microalgae), which may cause their feces to contain few inhibitors to Taq DNA polymerase. (ii) The modified phenol/chloroform method was effective in isolating DNA from feces. Taken together, the findings indicate that the modified phenol/chloroform method is effective in isolating DNA from feces, and fecal DNA from herbivorous animals can be used as a template for PCR amplification, which is also supported by the findings of Zhang et al.'s study on fecal DNA of pandas [37].

\section{Degradation of feces and fecal DNA under different soaking times and environmental temperatures}

Bioflocs are composed of microorganisms, protozoa, algae, filamentous bacteria, and organic matter in water [38]. With the decomposition of feces into flocs, the microbial community structure was altered. In the process of degradation, the structure of fecal pellets became loose, which increased the contact area with seawater, thereby increasing the attachments for protozoa and leading to a looser structure [39]. As shown in Fig. 3, differences were observed in the rate of fecal texture changes at different temperatures. The degradation rate at $28^{\circ} \mathrm{C}$ was significantly higher than that at $15^{\circ} \mathrm{C}$ and $4{ }^{\circ} \mathrm{C}$ after the same soaking time, which was probably due to the high temperature $\left(28^{\circ} \mathrm{C}\right)$ appropriate for the growth and reproduction of microorganisms in feces and improvement of the activity of fecal degradationrelated enzymes [40]. Moreover, fecal degradation was often accompanied by fecal DNA degradation (Fig. 4), and the degree of fecal DNA degradation was also affected by the environmental temperature. Similar phenomena were observed in feces of other animals. The quality of DNA isolated from feces of Canis lupus in winter remained significantly higher than that in summer [41]. Moreover, the quality of fecal DNA from ape was negatively correlated with fecal environmental temperature [42]. These findings suggest that fecal sampling should be conducted in seasons with low temperature to obtain good-quality fecal DNA [43-45].

The degradation of feces and fecal DNA was also affected by soaking time in seawater. The longer the soaking time, the more serious the degradation (Fig. 4). Several studies suggest that fecal DNA degradation is affected by water. The rate of fecal DNA degradation is significantly accelerated by rain wash [46], and removing water from feces can essentially prevent the activation of nuclease in feces [47]. Moreover, Cyclina sinensis is a kind of marine shellfish, and its feces are soaked in seawater. Seawater is a very complicated multicomponent aqueous solution containing various organic, inorganic, dissolved, and suspended substances, which may be the reason for the degradation of feces and fecal DNA from clam. Therefore, the fresher the fecal samples collected, the higher the quality of DNA [48].

\section{Conclusions}

In this study, clam feces were used as experimental material to isolate DNA noninvasively. The isolation of fecal DNA was found to be successful and reliable by PCR amplification. The effects of different environmental temperatures and soaking times on the degradation of feces and fecal DNA were investigated. The results suggest that fresh fecal samples stored at low environmental temperature $\left(\sim 4{ }^{\circ} \mathrm{C}\right)$ were beneficial to the isolation of fecal DNA with good quality. This study provides technical support for further molecular biology research and conservation genetics research of shellfish.

\section{Methods}

\section{Sampling and processing}

Healthy clams $C$. sinensis were collected from a clam farm in Jiangsu, China. They were cultured in seawater for two weeks at room temperature and fed with $0.005 \mathrm{~g} / \mathrm{mL}$ of Chlorella once a day. Natural seawater was filtered with a double-layer 500-mesh sieve after precipitation, disinfection, and aeration for culturing clams and replaced once a day.

Forty-eight healthy clams (body weight, $10.09 \pm 2.81 \mathrm{~g}$; shell length, $3.01 \pm 0.38 \mathrm{~cm}$ ) were randomly selected and divided into 12 parallel groups (labeled 1 to 12), each groups containing four clams. Feeding was withheld for 2 days in continuously oxygenated seawater. Thereafter, the clams were fed with $6 \times 10^{5}$ cells/L of Chlorella until waste matter (feces) was completely expelled. During this period, clam defecation was observed every $2 \mathrm{~h}$. The feces were collected from the bottom of the beaker using siphon method.

\section{DNA isolation}

Total DNA was isolated from clam feces and foot tissue (used as positive control). Fecal DNA isolation was performed using the phenol/chloroform method in accordance with a previous study of Sambrook [49] with some modifications as follows: 
1) Place the feces on a 200-mesh silk screen, and wash it slowly with double-distilled water $\left(\mathrm{ddH}_{2} \mathrm{O}\right)$ to remove impurities on the fecal surface.

2) Transfer each $200 \mathrm{mg}$ fecal sample into a new 1.5 $\mathrm{mL}$ Eppendorf tube.

3) Add $100 \mu \mathrm{L} d d \mathrm{H}_{2} \mathrm{O}$, blow the feces repeatedly with a straw to make it homogenate, and then vortex fully.

4) Centrifuge for $3 \mathrm{~min}$ at $800 \times \mathrm{g}$, and then transfer the supernatant into a new $1.5 \mathrm{~mL}$ tube. Add $400 \mu \mathrm{L}$ of $10 \%$ SDS and $10 \mu \mathrm{L}$ of proteinase $\mathrm{K}$ into each tube, and then vortex fully.

5) Incubate the tubes for $1 \mathrm{~h}$ in a $65^{\circ} \mathrm{C}$ water bath with occasional shaking ( $10 \mathrm{~min})$.

6) Add $10 \mu \mathrm{L}$ of $20 \mathrm{mg} / \mathrm{mL}$ RNase, and incubate the tubes in a $37^{\circ} \mathrm{C}$ water bath for $10 \mathrm{~min}$. Centrifuge for $3 \mathrm{~min}$ at $12,000 \times \mathrm{g}$, and then transfer the supernatant into a new $1.5 \mathrm{~mL}$ tube.

7) Add an equal volume of ice-cold Tris-saturated phenol ( $\mathrm{pH}$ 7.9), and mix upside down and store at room temperature for $5 \mathrm{~min}$.

8) Centrifuge at $12,000 \times \mathrm{g}$ for $12 \mathrm{~min}$, and then transfer the supernatant into a new $1.5 \mathrm{~mL}$ tube.

9) Add an equal volume of chloroform, and mix upside down. Centrifuge at $12,000 \times \mathrm{g}$ for $10 \mathrm{~min}$, and then transfer the supernatant into a new 1.5 $\mathrm{mL}$ tube.

10) Add an equal volume of isopropanol, mix upside down, and store at room temperature for $3 \mathrm{~min}$. Centrifuge at $12,000 \times \mathrm{g}$ for $12 \mathrm{~min}$, and then remove the supernatant completely.

11) Wash the DNA pellet twice with $1 \mathrm{~mL}$ ice-cold $70 \%$ ethanol.

12) Air dry.

13) Resuspend the DNA pellet in $30 \mu \mathrm{L}$ of TE buffer, and then store at $-40^{\circ} \mathrm{C}$ before use.

\section{Primer design and PCR amplification}

To determine DNA quality, PCR amplification was conducted with primers designed on the basis of mitochondrial and nuclear genomic DNA sequences. The sequences of mitochondrial (COXI and 16S rRNA) and nuclear genomic DNA (18S rRNA and partial sequence of nuclear DNA) were retrieved and downloaded from NCBI (https://www.ncbi.nlm.nih.gov/). PCR primers were designed by Primer Premier 5.0 software and are shown in Table 2. PCR amplification was conducted in a $15 \mu \mathrm{L}$ reaction volume, containing $1.0 \mu \mathrm{L}$ of DNA template, $0.2 \mu \mathrm{L}$ of Taq (Takara, Dalian, China), $0.8 \mu \mathrm{L}$ of primers (including forward and reverse primers), $1.0 \mu \mathrm{L}$ of dNTPs, $1.5 \mu \mathrm{L}$ of $10 \times$ buffer, and $10.5 \mu \mathrm{L}$ of $\mathrm{dd}_{2} \mathrm{O}$. The PCR amplification procedure was conducted as follows: initial denaturation at $95^{\circ} \mathrm{C}$ for $5 \mathrm{~min}$, followed by 30 cycles of denaturation at $94^{\circ} \mathrm{C}$ for $1 \mathrm{~min}$, annealing for $30 \mathrm{~s}$, extension at $72{ }^{\circ} \mathrm{C}$ for $30 \mathrm{~s}$, and final extension at $72{ }^{\circ} \mathrm{C}$ for $10 \mathrm{~min}$. The PCR amplification products were detected by $1.5 \%$ agarose gel electrophoresis and captured with a gel imaging system (Universal Hood II, Bio-Rad, USA). The purified PCR products were sequenced by Shanghai Map Biotech Co., Ltd. The sequencing results were checked by Chromas software and blasted by BLAST online software (https://blast.ncbi. nlm.nih.gov/Blast.cgi).

\section{Effects of soaking time and environmental temperature on the degradation of feces and fecal DNA}

To explore the effects of environmental temperature and soaking time on fecal texture changes and fecal DNA degradation, the fecal samples were collected immediately after the clams defecated. They were then soaked in clean seawater and stored at $28^{\circ} \mathrm{C}$, $15^{\circ} \mathrm{C}$, and $4{ }^{\circ} \mathrm{C}$. To observe fecal texture changes, the fecal samples were placed on clean slides, observed, and photographed with a stereoscope (Nikon SME 1500, Nikon, Japan) at 0, 5, 10, 15, 20, and 25 days after soaking in seawater. Fecal DNA isolation was conducted using the modified phenol/chloroform method mentioned above, and the fecal DNA quality was determined by Ultramicro Nucleic Acid Analyser (Eppendorf BioPhotometer ${ }^{\circ}$ D30, Eppendorf, Germany), electrophoresis, and PCR amplification.

Table 2 Primers and sequences

\begin{tabular}{|c|c|c|c|c|}
\hline Primer & Sequence $\left(5^{\prime}-3^{\prime}\right)$ & Source & Gene ID & Product size/bp \\
\hline \multirow[t]{2}{*}{$\mathrm{CsCOXI}$} & F:TGGTGGTTTAACTGGTGTTGTT & Mitochondrial DNA & $26,898,108$ & 404 \\
\hline & R:AAAACACCAAACCACGCTGAG & from C. sinensis & & \\
\hline \multirow[t]{2}{*}{ Cs16S } & F:GATCGTACCTGCCCTGTGAT & Mitochondrial DNA & $26,898,076$ & 548 \\
\hline & R:ACCACTCTAGCTTACGCCGA & from C. sinensis & & \\
\hline \multirow[t]{2}{*}{ Cs18S } & F:TGCGTTCAAGGTGTCGATGT & Nuclear genomic & unregistered & 581 \\
\hline & R:GGGGCCGACATGAAATGAAA & DNA from C. sinensis & & \\
\hline \multirow[t]{2}{*}{ Cspds } & F: ACTTCAGAATTCAGAATTCAG & Nuclear genomic & unregistered & 187 \\
\hline & R: GTCACGCACAATGTAACG & DNA from C. sinensis & & \\
\hline
\end{tabular}




\section{Data analysis}

The DNA purity was confirmed by Ultramicro Nucleic Acid Analyser (Eppendorf BioPhotometer ${ }^{\circ}$ D30, Eppendorf, Germany). The DNA and PCR amplification products were detected by 1 and 1.5\% agarose gel electrophoresis respectively, and the gel images were observed and captured with a gel imaging system (Universal Hood II, Bio-Rad, America).

\section{Supplementary information}

Supplementary information accompanies this paper at https://doi.org/10. 1186/s12896-019-0595-6.

Additional file 1: Figure S1. Agarose gel electrophoresis of fecal DNA. Lane M, DNA marker; lane N, negative control; lane F, foot DNA; lanes 120, DNA of fresh feces $(N=20)$.

Additional file 2: Figure S2. Agarose gel electrophoresis of PCR amplification products Lane M, DNA marker; lane N, negative control; lane F, PCR amplification products of foot DNA; lanes 1-20, PCR amplification products of fecal DNA $(N=20)$.

Additional file 3: Figure S3. Agarose gel electrophoresis of PCR amplification products from clam feces under different soaking times and environmental temperatures. Samples stored at $28^{\circ} \mathrm{C}(\mathrm{a}), 15^{\circ} \mathrm{C}(\mathrm{b})$, and $4^{\circ} \mathrm{C}$ (c). Lane M, DNA marker; lane $\mathrm{N}$, negative control; lane F, foot DNA of clam; lanes 1-12, fecal DNA.

\section{Abbreviations}

C. sinensis: Cyclina sinensis; PCR: Polymerase chain reaction; rDNA: Ribosomal DNA; rRNA: Ribosomal RNA

\section{Acknowledgments}

The authors would like to express our appreciation to Guangen Xu for trial sample preparation, and thanks to Essaystar for modification-polish.

\section{Authors' contributions}

$M Z, M W$ and ZD conceived and designed the experiments. MZ performed the experiments. KY, HL, SM, HD, SF, ZS, WL, JL contributed materials. MZ and MW analyzed the data and wrote the manuscript. XM and $H G$ guided the experiments and writing. All authors read, reviewed and approved the manuscript.

\section{Funding}

This study was supported by grants from China Agriculture Research System (CARS-49), the Priority Academic Program Development of Jiangsu, the Natural Science Foundation of the Jiangsu Higher Education Institutions of China (No. 18KJA240001), the Project of Jiangsu Fisheries Science and Technology (Y2018-27), the Project of Jiangsu Key Laboratory of Marine Biotechnology (No. HS2018002), the Postgraduate Research \& Practice Innovation Program of Jiangsu Province (No. SJCX18_0932), and the Undergraduate Innovation and Entrepreneurship Training Program of Jiangsu Ocean University (Z201911641105018). The funding bodies did not play any role in the design of the study, the collection, analysis, and interpretation of data and in writing the manuscript.

\section{Availability of data and materials}

The datasets analyzed during the current study are available from the corresponding author on reasonable request.

\section{Ethics approval and consent to participate}

All applicable institution and/or national guidelines for the care and use of animals were followed.

\section{Consent for publication}

Not applicable.

\section{Competing interests}

The authors declare that they have no competing interests.
Received: 15 August 2019 Accepted: 10 December 2019

Published online: 19 December 2019

\section{References}

1. Nakamura Y, Kerciku F. Effects of filter-feeding bivalves on the distribution of water quality and nutrient cycling in a eutrophic coastal lagoon. J Mar Syst. 2000;26:209-21.

2. Lin TT, Zhou K, Liu X, Lai QF, Zhang D, Shi LY. Effects of clam size, food type, sediment characteristic, and seawater carbonate chemistry on grazing capacity of Venus clam Cyclina sinensis (Gmelin, 1791). Chin J Oceanol Limnol. 2016:35:1239-47.

3. Taberlet $P$, Waits LP, Luikart G. Noninvasive genetic sampling: look before you leap. Trends Ecol Evol. 2008;14:323-7.

4. Cheng HL, Xia DQ, Wu TT, Meng XP, Ji HJ, Dong ZG. Study on sequences of ribosomal DNA internal transcribed spacers of clams belonging to the Veneridae Family (Mollusca: Bivalvia). Acta Genet Sin. 2006;33(8):702-10.

5. Morin PA, Woodruff DS. Noninvasive genotyping for verteb rate conservation. Mol Genet Approaches Conserv. 1996. p. 298-313.

6. Fernández-Alacid L, Sanahuja I, Ordóñez-Grande B, Sánchez-Nuño S, Viscor G, Gisbert E, Herrera M, Ibarz A. Skin mucus metabolites in response to physiological challenges: a valuable non-invasive method to study teleost marine species. Sci Total Environ. 2018:644:1323-35.

7. Wasko AP, Martins C, Oliveira C, Foresti F. Non-destructive genetic sampling in fish. An improved method for DNA extraction from fish fins and scales. Hereditas. 2010;138(3):161-5.

8. Reed JZ, Tollit DJ, Thompson PM, Amos W. Molecular scatology: the use of molecular genetic analysis to assign species, sex and individual identity to seal faeces. Mol Ecol. 1997;6:225-34

9. Parsons KM. Reliable microsatellite genotyping of dolphin DNA from faeces. Mol Ecol Notes. 2001;:1:341-4.

10. Chancellor RL, Langergraber K, Ramirez S, Rundus AS, Vigilant L. Genetic sampling of unhabituated chimpanzees (Pan troglodytes schweinfurthii) in Gishwati forest reserve, an isolated forest fragment in Western Rwanda. Int J Primatol. 2012;33:479-88

11. Lathuillière M, Ménard N, Gautier-Hion A, Crouau-Roy B. Testing the reliability of noninvasive genetic sampling by comparing analyses of blood and fecal samples in Barbary macaques (Macaca sylvanus). Am J Primatol. 2010;55:151-8

12. King SRB, Schoenecker KA, Fike J, Oyler-McCance SJ. Long-term persistence of horse fecal DNA in the environment makes equids particularly good candidates for noninvasive sampling. Ecology Evolution. 2018:8:4053-64.

13. Zhu Y, Liu HY, Yang HQ, Li YD, Zhang HM. Factors affecting genotyping success in giant panda fecal samples. Peer J. 2017;5(5):e3358.

14. Zhang BW, Li M, Ma LC, Wei FW. A widely applicable protocol for DNA isolation from fecal samples. Biochem Genet. 2006;44(11-12):494-503.

15. Yamashiro A, Yamashiro T, Baba M, Endo A, Kanmada M. Species identification based on the faecal DNA samples of the Japanese serow (Capricornis crispus). Conserv Genet Resour. 2010:2:409-14.

16. Laguardia A, Wang J, Shi FL, Shi K, Riordan P. Species identification refined by molecular scatology in a community of sympatric carnivores in Xinjiang, China. Zool Res. 2015;36(2):72-8.

17. Modi S, Mondol S, Ghaskadbi P, Hussain Z, Nigam P, Habib B. Noninvasive DNA-based species and sex identification of Asiatic wild dog (Cuon alpinus). J Genet. 2018;97(5):1457-61.

18. Brinkman TJ, Person DK, Schwartz MK, Pilgrim KL, Colson KE, Hundertmark KJ. Individual identification of Sitka blacktailed deer (Odocoileus hemionus sitkensis) using DNA from fecal pellets. Conserv Genet Resour. 2010;2:115-8.

19. Ruiz-González A, Madeira MJ, Randi E, Urra F, Gómez-Moliner BJ. Noninvasive genetic sampling of sympatric marten species (Martes martes and Martesfoina): assessing species and individual identification success rates on faecal DNA genotyping. Eur J Wildl Res. 2013;59:371-86.

20. Yamashiro A, Kaneshiro Y, Kawaguchi Y, Yamashiro T. Species, sex, and individual identification of Japanese serow (Capricorni scrispus) and sika deer (Cervus nippon) in sympatric region based on the fecal DNA samples. Conserv Genet Resour. 2017:9:333-8.

21. Liu J, Bao YX, Wang YN, Zhang WC, Chen XN, He WP, Shi WW. Individual and sexual identification for the wild black muntjac (Muntiacus crinifrons) based on fecal DNA. Acta Ecol Sin. 2014:34:13-8.

22. Murphy MA, Waits LP, Kendall KC. The influence of diet on faecal DNA amplification and sex identification in brown bears (Ursus arctos). Mol Ecol. 2010;12:2261-5 
23. Yamauchi K, Hamasaki S, Miyazaki K, Kikusui T, Takeuchi Y, Mori Y. Sex determination based on fecal DNA analysis of the amelogenin gene in sika deer (Cervus nippon). J Vet Med Sci. 2000;62(6):669-71.

24. Liu X, Yang YY, Wang XM, Liu ZS, Wang ZH, Ding YZ. Sex identification based on AMEL gene PCR amplification from blue sheep (Pseudois nayaur) fecal DNA samples. Genet Mol Res. 2015;14(3):9045-52.

25. Yamazaki S, Motoi Y, Nagai K, Ishinazaka T, Asano M, Suzuki M. Sex determination of sika deer (Cervus nippon yesoensis) using nested PCR from feces collected in the field. J Vet Med Sc. 2011;73(12):1611-6.

26. Saito W, Amaike Y, Sako T, Kaneko Y, Masuda R. Population structure of the raccoon dog on the grounds of the imperial palace, Tokyo, revealed by microsatellite analysis of fecal DNA. Zool Sci. 2016;33(5):485-90.

27. Wultsch C, Caragiulo A, Dias-Freedman I, Quigley H, Rabinowitz S, Amato G. Genetic diversity and population structure of Mesoamerican jaguars (Panthera onca): implications for conservation and management. PLoS One. 2016;11(10):e0162377.

28. Mekonnen A, Rueness EK, Stenseth NC, Fashing PJ, Bekele A, HernandezAguilar RA, Missbach R, Haus T, Zinner D, Roos C. Population genetic structure and evolutionary history of bale monkeys (Chlorocebus djamdjamensis) in the southern Ethiopian highlands. BMC Evol Biol. 2018;18(1):106.

29. Sugimoto T, Aramilev W, Kerley LL, Nagata J, Miquelle DG, McCullough DR. Noninvasive genetic analyses for estimating population size and genetic diversity of the remaining far eastern leopard (Panthera pardus orientalis) population. Conserv Genet. 2014;15:521-32.

30. Espinosa MI, Bertin A, Squeo FA, Cortés A, Gouin N. Comparison of DNA extraction methods for polymerase chain reaction amplification of guanaco (Lama guanicoe) fecal DNA samples. Genet Mol Res. 2015;14(1):400-6.

31. Frantzen MA. SilkJB, Ferguson JW, Wayne RK, Kohn MH. Empirical evaluation of preservation methods for faecal DNA. Mol Ecol. 1998;7:1423-8.

32. Femando P, Vidya TN, Rajapakse C, Dangolla A, Melnick JD. Reliable noninvasive genotyping: fantasy of reality? J Hered. 2003;94:115-23.

33. Lonsinger RC, Gese EM, Dempsey SJ, Kluever BM, Johnson TR, Waits LP. Balancing sample accumulation and DNA degradation rates to optimize noninvasive genetic sampling of sympatric carnivores. Mol Ecol Resour. 2015;15(4):831-42.

34. lacovacci G, Serafini M, Berti A, Lago G. STR typing from human faeces: a modified DNA extraction method. Int Congr Ser. 2003;1239:917-20.

35. Sidransky D, Tokino T, Kinzler SR, Hamilton KW, Levin B, Frost $P$, Vogelstein $B$. Identification of ras oncogene mutations in the stool of patients with curable colorectal tumors. Science. 1992;256:102-5.

36. Carss DN, Parkinson SG. Errors associated with otter (Lutra lutra) fecal analysis. I. Assessing general diet from spraints. J Zool. 1996:238:301-17.

37. Zhang BW, Wei FW, Li M, Lv XP. A simple protocol for DNA extraction from faeces of the giant panda and lesser panda. Acta Zool Sin. 2004:50:452-8.

38. Xia Y, Yu EM, Xie J, Yu DG, Wang GJ, Li ZF, Wang HY, Gong WB. Analysis of bacterial community structure of bio-Floc by PCR-DGGE. J Fish China. 2012; 36:1563-71.

39. Poulsen L, Iversen M. Degradation of copepod fecal pellets: key role of protozooplankton. Mar Ecol Prog. 2008;367:1-13.

40. Saborowski R, Friedrich M, Dietrich U, Gutow $L$. The degradation of organic material from invertebrate fecal pellets by endogenous digestive enzymeseffects of $\mathrm{pH}$ and temperature, 2nd annual meeting: biological impacts of ocean acidification. Germany: Bremen; 2011

41. Lucchini V, Fabbri E, Marucco F, Ricci S, Boitani L, Randi E. Noninvasive molecular tracking of colonizing wolf (Canis lupus) packs in the western Italian Alps. Mol Ecol. 2002;11:857-68.

42. Nsubuga AM, Robbins MM, Roeder AD, Morin PA, Boesch C, Vigilant L. Factors affecting the amount of genomic DNA extracted from ape faeces and the identification of an improved sample storage method. Mol Ecol. 2004:13:2089-94.

43. Maudet C, Luikart G, Dubray D, Von Hardenberg A, Taberlet P. Low genotyping error rates in wild ungulate faeces sampled in winter. Mol Ecol Notes. 2004:4:772-5.

44. DeMay SM, Becker PA, Eidson CA, Rachlow JL, Johnson TR, Waits LP. Evaluating DNA degradation rates in faecal pellets of the endangered pygmy rabbi. Mol Ecol Resour. 2013;13:654-62.

45. Hu YB, Nie YG, Wei W, Ma TX, Horn VR, Zheng XG, Swaisgood RR, Zhou ZX, Zhou WL, Yan L, Zhang ZJ, Wei FW. Inbreeding and inbreeding avoidance in wild giant pandas. Mol Ecol. 2017;26:5793-806.

46. Agetsuma $Y Y$, Inoue $E_{1}$ Agetsuma N. Effects of time and environmental conditions on the quality of DNA extracted from fecal samples for genotyping of wild deer in a warm temperate broad-leaved forest. Mamma Res. 2017:62:1-7.

47. Beja-Pereira A. OliveiraR, Alves PC, Schwartz MK, Luikart G. advancing ecological understandings through technological transformations in noninvasive genetics. Mol Ecol Resour. 2009;9:1279-301.

48. Reddy PA, Bhavanishankar M, Bhagavatula J, Harika K, Mahla RS, Shivaji S. Improved methods of carnivore faecal sample preservation, DNA extraction and quantification for accurate genotyping of wild tigers. PLOS One. 2012;7: e46732.

49. Sambrook J, Fritsch EF, Maniatis T. Molecular cloning: a laboratory manual 2nd ed. Cold Spring Harbor: Cold Spring Harbor Laboratory Press; 1989.

\section{Publisher's Note}

Springer Nature remains neutral with regard to jurisdictional claims in published maps and institutional affiliations.
Ready to submit your research? Choose BMC and benefit from:

- fast, convenient online submission

- thorough peer review by experienced researchers in your field

- rapid publication on acceptance

- support for research data, including large and complex data types

- gold Open Access which fosters wider collaboration and increased citations

- maximum visibility for your research: over $100 \mathrm{M}$ website views per year

At BMC, research is always in progress.

Learn more biomedcentral.com/submissions 